\title{
Lay morality, clerical immorality, and pilgrimage in tenth-century Ireland: Cethrur macclérech and Epscop do Gáedelaib ${ }^{1}$
}

\author{
ELIZABETH BOYLE \\ (National University of Ireland, Maynooth)
}

The subject of the present study is a pair of medieval Irish ecclesiastical anecdotes, namely Cethrur macclérech ('Four Junior Clerics') and Epscop do Gáedelaib ('A Bishop of the Gaels'). Insofar as they have received any scholarly attention, these brief narratives, and others which possess a similar form, have been characterised as Christian exempla. ${ }^{2}$ However, identifying their moral or didactic purpose is by no means straightforward: they are rich and complex narratives, bristling with puns, double meanings and moral ambiguity. In their incidental details, they shed light on various aspects of the ecclesiastical culture of early medieval Ireland. The purpose of this essay is to present editions, translations and close readings of both Cethrur macclérech and Epscop do Gáedelaib, to put forward possible interpretations of both texts, and to suggest a wider intellectual and historical framework within which this type of text might have functioned. Both texts are preserved in Lebor na Nuachongbála (TCD MS H 2. 18 (1339), now commonly known as the Book of Leinster, henceforth LL), a twelfth-century Irish manuscript which contains a multiplicity of vernacular historical, ecclesiastical and literary sources; both texts are written in the hand

${ }^{1}$ I would like to thank the members of the Medieval Irish Reading Group, Department of Anglo-Saxon, Norse and Celtic, University of Cambridge, who read a selection of anecdotes from the Book of Leinster with me and discussed innumerable points of linguistic, literary and historical interest, many of which I have incorporated here. The group comprised Professor Liam Breatnach, David Callander, Dr Rob Crampton, Dr Matthias Egeler, Dr Margo Griffin-Wilson, Sarah Lackner, Dr Máire Ní Mhaonaigh, Veronica Phillips, Julianne Pigott, Professor Paul Russell, Radu Razvan Stanciu, and Sarah Waidler. I am also grateful to Liam Breatnach for detailed information on the language and orthography of the Leabhar Breac. The material discussed here was presented at an Earlier Middle Ages seminar at the Institute of Historical Research, London, in May 2013, and at the Tionól, Dublin Institute for Advanced Studies, in November 2013, and I am greatly indebted to those who attended for their stimulating and useful comments. Any errors which remain are my own.

${ }^{2}$ Dagmar Schlüter, History or fable? The Book of Leinster as a document of cultural memory in twelfth-century Ireland (Münster, 2010), 206-10, where they are also described as 'normative texts' and 'perhaps ... a didactic form of Christian historiography' (p. 210). This characterisation seems to miss their more subtle and ambiguous nature. 
known as $\mathrm{F}^{3}$ They are to be found towards the end of the manuscript, alongside other brief narratives, many of which are set in foreign locations, are structured in a formulaic fashion, and use irreverent humour and wordplay as a strategy for conveying important moral and religious lessons. ${ }^{4}$ Cethrur macclérech and Epscop do Gáedelaib are of particular interest because they provide biting commentaries on clerical and lay morality, and suggest a sceptical view of the spiritual value of pilgrimage.

The formulaic structure which underlies both narratives can be summarised thus: they begin with a clerical protagonist, or protagonists, heading on pilgrimage to Rome. They decide not to return to Ireland, and this decision involves them encountering a foreign king, in whose kingdom they remain for a period of time. The king is more pious than the cleric(s), and permits them to stay in his kingdom, offering them a favour, and in return establishing an obligation of prayer and/or spiritual direction on the part of the cleric(s). Lay morality is further emphasised by the repeated, and frequently ironic, use of the word maith ('good', 'good thing', 'well' or 'fine'). The clerical protagonists then get themselves into some sort of trouble as a result of their own sinfulness; but, through God's miraculous intervention, they are saved and are permitted to continue with their foreign sojourn. Each anecdote ends with a statement of its purported moral, although I would argue that in both cases the stated moral is not in fact the real moral of the tale. The moral heart of each anecdote is, I suggest, expressed by the king at an earlier point in the narrative: in the case of Cethrur macclerech it is that God created every day equally and therefore no one day is luckier than another;

\footnotetext{
${ }^{3}$ The diplomatic edition of the manuscript is R. I. Best et al. (eds), The Book of Leinster, formerly Lebar na Núachongbála (6 vols, Dublin, 1954-83). See volume 5 for Cethrur macclérech (p. 1229) and Epscop do Gáedelaib (p. 1230). See also the important recent discussion of LL by Elizabeth Duncan, 'A reassessment of the script and make-up of Lebor na Nuachongbála', Zeitschrift für celtische Philologie 59 (2012), 27-66, which develops and refines William O'Sullivan's fundamental study, 'Notes on the scripts and make-up of the Book of Leinster', Celtica 7 (1966), 1-31. The LL copy of Cethrur macclérech was previously translated by Kuno Meyer ('Anecdota from Irish MSS. XII', The Gaelic Journal 5 (1894), 64 and 79-80); as far as I am aware, Epscop do Gáedelaib has not previously been translated.

${ }^{4}$ Thus, for example, the text which follows immediately after Epscop do Gáedelaib, beginning Baí rí amra de Grécaib, which is a vernacular, humorous reworking of an episode derived from the apocryphal book of 3 Esdras, on the relative potency of alcohol, kings and women: Best et al. (eds), The Book of Leinster, v, 1231; Máire Herbert and Martin McNamara (trans.), Irish biblical apocrypha: selected texts in translation (Edinburgh, 1989), 23-4. The location of the apocryphal narrative, at the court of the Persian king Darius, is shifted in the Irish anecdote to the court of the mythological Greek king Salmoneus. The text is also preserved in a very closely related version in the Yellow Book of Lecan.
} 
LAY MORALITY, CLERICAL IMMORALITY, \& PILGRIMAGE . . .

in the case of Epscop do Gáedelaib it is that God exists everywhere equally and therefore one is no more likely to encounter Him on pilgrimage than anywhere else. A close reading of each text reveals further layers of complexity, irony and moral ambiguity.

\section{CETHRUR MACCLÉRECH}

Cethrur macclérech is preserved in two manuscripts, namely, LL and Oxford, Bodleian Library MS Rawlinson B 512, f. 144r $144 \mathrm{v}$ (henceforth B). It tells of four Irish junior clerics (or clerical adherents, if we accept Colmán Etchingham's suggestion that maccléirig should be so translated) ${ }^{5}$ who are on pilgrimage to Rome. They seek hospitality in Francia, where they are impressed by the generosity of their host, and particularly the abundant wine and wheat-bread which he offers them. They formulate a plan that, on their return from Rome, they should request a hermitage where they can withdraw from society and yet conveniently continue to enjoy the liberality of produce on offer in Francia. Their wish is granted, though only after the eviction of a hermit who was already occupying the hermitage, and the Irish clerics express delight at their good luck. However, their reference to 'luck' causes the displeasure of the Frankish king, who throughout the text exhibits far more piety than the opportunistic young clerics. He accuses them of heathenism, and banishes them from his kingdom. They travel for the space of a day until they reach a city. The next morning, their bishop (who suddenly appears in the narrative at this point) sees a wooden chest, floating miraculously against the current of the river, and he orders a lad to take it to the king. The king orders that the chest be opened, and discovers six bars of silver and one of gold therein. Upon weighing the bars, it is observed that none weighs any more than another. The king summons the clerics to him and interprets the significance of the contents of the chest as being that the bars signify the days of the week but, as no bar weighs more than another, so no day is luckier than another. He allows the clerics to remain in his kingdom, on condition that they never think about the idea of 'luck' for the rest of their lives. The narrative ends with the injunction that it is wrong to adhere to luck or augury.

The injunction with which the text concludes is problematic, in that the clerics did profit from their adherence to the idea of luck, since God miraculously intervened in order to ensure that they might be allowed to remain in Francia, amidst the abundant produce. The

${ }^{5}$ Colmán Etchingham, Church organisation in Ireland, A.D. 650-1000 (Maynooth, 1999), 249 n. 1. See commentary below, p. 17. 
clerics themselves demonstrated no repentance or regret over their superstitious utterance. This sense of moral ambiguity is heightened when we read the anecdote more closely and realise that it is replete with puns and irony (see commentary below).

\section{Language}

The language of the text is very early Middle Irish, perhaps datable to the tenth century. Significant Old Irish or very early Middle Irish forms include: Atlochur ( $\$ 4$, from ad-tluichethar; later a simple verb atlaigid); atacomnaic ( $\$ 4,3$ pl. infixed pronoun); Docuirethar ( $\$ 5$, deponent ending); and Berair ( $\$ 6$, Old Irish passive form, no dental). Other early features include: nann ( $\$ 5$ in B; nasalisation of ann caused by preceding accusative, cf. Thes. Pal. II, p. 242, §13, 1 . 8-9 and $\S 14,1.12)$; di sund (\$7, would later expect díb se or díb sin); dún (§6, later dúinn, cf. B); it é (§7, later is iad, cf. B); nicon (§6, cf. Nocon earlier in the same paragraph); comrair ( $\$ 5$ in B; cf. comraid in LL; see DIL s.v. comrar).

Significant Middle Irish features include: tairchellsatar $(\S 3$, deponent ending, for Old Irish tairchellsat) and Robarbia ( $\$ 3$, for Old Irish rob bia). Other Middle Irish features include: Cethrur macclérech (§1, in Old Irish one would expect cardinal + noun); Nocon (§6, but cf. Old Irish nicon in same paragraph); Dognít (§1, for Old Irish dogniat, cf. B); archena (§2, for Old Irish olchenae); i fechtsa (§4, see DIL s.v. fecht); dosrat (§7, for Old Irish dodarat); Oslaicthir (as a simple verb in §6). However, none of these seem to be incompatible with an early Middle Irish date. We see none of the characteristic features of late Middle Irish, found in other LL texts, such as independent pronouns as object of a verb. B has generally been modernised - particularly in terms of orthography in comparison with LL, but, as noted above, occasionally perhaps preserves an older form. With the exception of the final sentence, the two witnesses are remarkably similar.

\section{Edition}

Here I offer the text of Cethrur macclérech from the version in LL, with variants from B. ${ }^{6}$ My text is based on the diplomatic edition of LL, but I have expanded didiu and have added punctuation, paragraph divisions and capitalisation silently to reflect my interpretation of the text.

\footnotetext{
${ }^{6}$ Digital images are available at: www.image.ox.ac.uk.
} 
Text

(§1) Cethrur macclerech do feraib Herend dochótar ${ }^{7}$ ina n-ailithre do dul do Róim. ${ }^{8}$ Dognít $^{9}$ a n-oegidecht ${ }^{10}$ la fer n-amra do Frañcaib oc dul do Róim. Dobreth ${ }^{11}$ fín cruithnecht dóib. ${ }^{12}$ Maith doib.

(§2) 'Is ed as maith dún trá acallam ind fir maithse $\mathrm{e}^{13}$ iar tuidecht ${ }^{14}$ dún ${ }^{15}$ ó Róim co $n$ darda nach ñdísert dún ${ }^{16}$ sund co rrabam inar ${ }^{17} \mathrm{n}$-ailithre and, $\operatorname{ar}^{18}$ is imda cach torad and eter fín ${ }_{7}$ chruithnecht ${ }^{19}{ }_{7}$ cach torud archena. ${ }^{20}$

(§3) 'Fochen dúib,' or in laech. 'Robarbia ${ }^{21}$ mo maithse. Tabraidsi dano for ${ }^{22}$ maith damsa .i. guide Dé erom.' Dognither ón. Tiagait ${ }^{23}$ co tairchellsatar relic ${ }_{7}$ martra Petuir ${ }_{7}$ Phóil. Tecait anair doridisi.

(§4) 'Cuinnegar tra baile ${ }^{24}$ coro falmaigther dúib. ${ }^{25}$ 'Atá disert bec sund. Atá ${ }^{26}$ disertach trúag and.' 'Apar ${ }^{27}$ fris tuidecht ${ }^{28}$ ass,' or in rí.

'Atlochur do Dia,' ol in disertach. 'Mo rí talmanda dom brith $^{29}$ ass ${ }_{7}$ mo rí nemda ${ }^{30}$ do thuidecht ${ }^{31}$ ind. Aircid ind a chlerchu i fechtsa.'

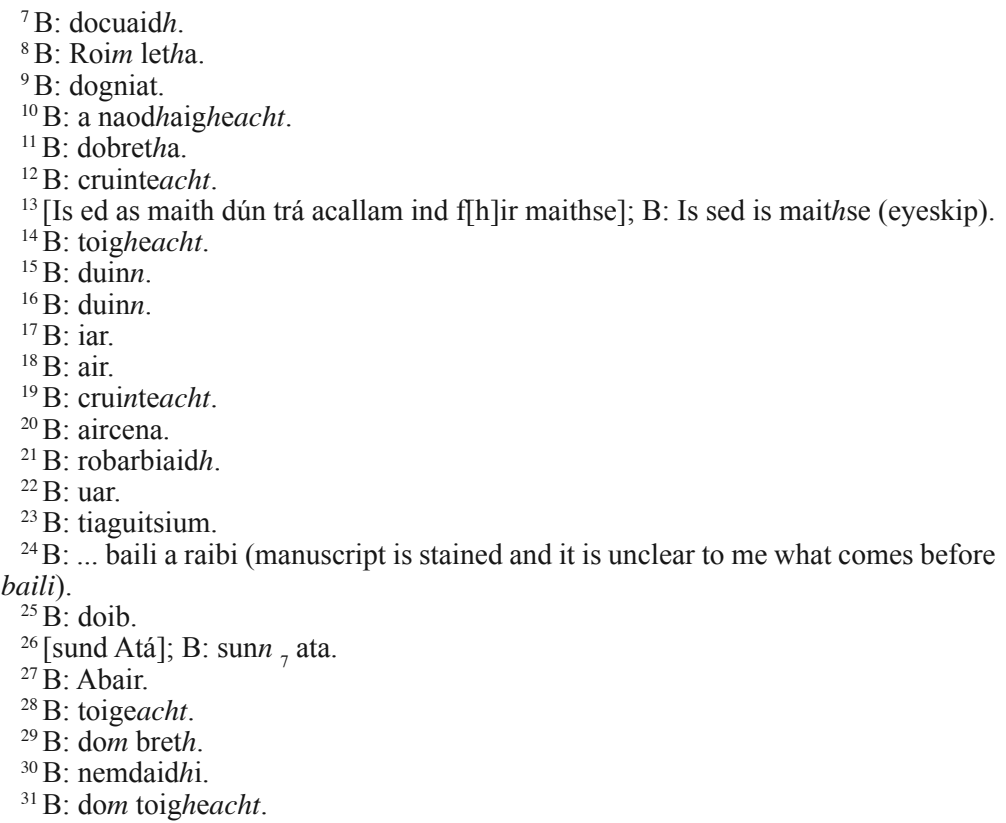


'Corop solaid,' ${ }^{32}$ or $^{33}$ in clerech.

'Cid asberat?' or in ri.

'Corop solaid dóib. ${ }^{34}$

'As tír ${ }^{35}$ dóib,' or in rí. 'Gentlide ${ }^{36}$ atacomnaic. ${ }^{37} \mathrm{Na}$ hebat ${ }^{38}$ cid usce in tíre.'

(§5) Tiagait ass ${ }^{39}$ uide ind laisin co rrancatar $^{40}$ cathraig $^{41}$ and. ${ }^{42}$ Buí in t-epscop .i. a toisechsom oc indmut a lám assin tsiruth arnabarach. ${ }^{43}$ Co n-accai ${ }^{44}$ comraid $^{45}$ craind frithrose in ts̉rotha chucai. ${ }^{46}$ Docuirethar bedg anís co mbuí $\mathrm{i}^{47} \mathrm{n}$-ucht in chlerig.

(§6) 'Beir ${ }^{48}$ latt a gillai ${ }^{49}$ dond ríg so, ${ }^{50}$ or in clerech. 'Nocon ${ }^{51}$ fetarsa cid fil and.'

Berair dó iarum..$^{52}$ Oslaicthir leis, ${ }^{53}$ co n-acca sé tinni argait inti $^{54}{ }_{7}$ tinne dergóir eturru. Ro curthea leis ${ }^{55}$ i mmeid. Nicon rabi ${ }^{56}$ méit friged ${ }^{57} \mathrm{i}$ nnach ${ }^{58}$ ae díb sech araile.

'Maith,' or se, 'congartar ${ }^{59}$ dún $^{60}$ na clerig.'

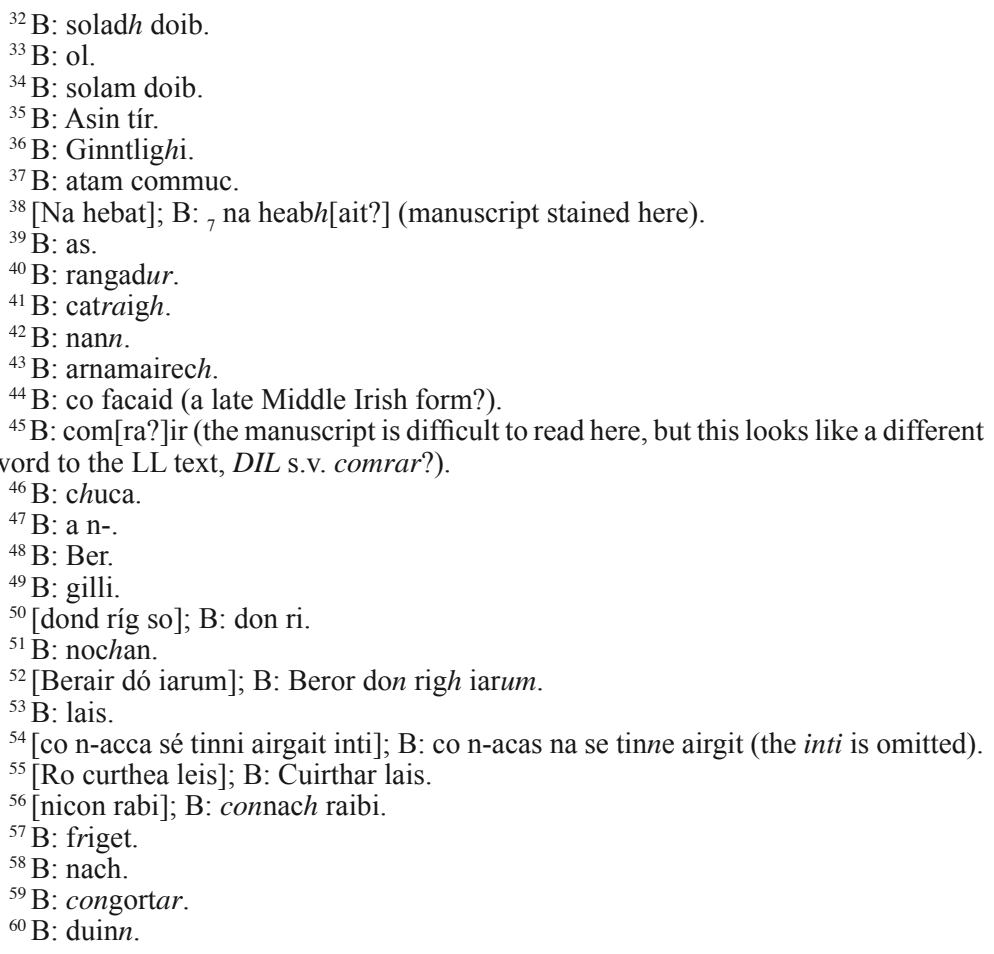


(§7) Dorochet $^{61}$ iarum.

'Maith, a chlerchiu, atá sund ar n-etargléod na secht ${ }^{62}$ tinnese amne .i. na se tinni argait ${ }^{63}$ it é sé lathe ${ }^{64}$ na sechtmaine. In ${ }^{65}$ tinne óir is hé in domnach in $\sin .{ }^{66}$ Is $e d$ atchíu ni trummu ${ }^{67}$ ní sech araile ${ }^{68}$ díb. Is é a etargnaside didiu amal nach trummu ${ }^{69}$ tinni di sund sech araile. Is amlaid soluid ${ }^{70}$ laí $^{71}$ sech araile don tsechtmain. $\mathrm{Ar}^{72}$ is óenrí dosrat ${ }^{73}$ ni tharat ${ }^{74}$ olc for nach ae sech araile. ${ }^{75}$ Anaidsi $^{76}$ a chlerchu, ${ }^{77}$ itib $^{78}$ degdoene, acht chena $^{79}$ na imradid ${ }^{80}$ solud céin bethi i mbethaid. ${ }^{91}$

(§8) Connach cóir didiu lenmain do solud ł sénairecht. ${ }^{82}$

\section{Translation}

(§1) Four junior clerics of the men of Ireland went on their pilgrimage to go to Rome. They are put up by a renowned man of the Franks on the way to Rome. Wine and wheatbread was given to them. It was good with them.

(§2) 'It is this that is good for us, then, to speak to this good man after we come back from Rome, so that he may give us some hermitage here, so that we may be in our pilgrimage in it, for every produce is plentiful in it, including wine and wheat-bread and every other produce'.

\footnotetext{
${ }^{61} \mathrm{~B}$ : dorethet (do-reith, 'to run up/hasten').

${ }^{62}$ [ar n-etargléod. Na secht]; B: a n-eitirgleod $h$ na secht.

${ }^{63} \mathrm{~B}$ : airgid $h$ (? unclear to me whether the lenition of $\mathrm{d}$ is indicated or not).

${ }^{64}$ [it é sé lathe]; B: .i. se laithi.

${ }^{65} \mathrm{~B}:$ in.

${ }^{66}$ [óir is hé in domnach in sin]; B: óir an domnach an $n \sin$.

${ }^{67} \mathrm{~B}$ : truime.

${ }^{68}$ [ní sech araile]; B: nach ai sech araile.

${ }^{69} \mathrm{~B}$ : [illegible].

${ }^{70} \mathrm{~B}$ : [nach?] soluid (there is something before the soluid - maybe nach - but it is hard to read here).

${ }^{71} \mathrm{~B}$ : la.

${ }^{72}$ B: Air.

${ }^{73} \mathrm{~B}$ : dosroine ('made', late Middle Irish form).

${ }^{74} \mathrm{~B}$ : ni tart.

${ }^{75}$ [olc for nach ae sech araile]; B: olc ar la sech araile.

${ }^{76} \mathrm{~B}$ : [illegible - perhaps anaidsium?]

${ }^{77} \mathrm{~B}$ : cleirciu.

${ }^{78} \mathrm{~B}$ : atib.

${ }^{79} \mathrm{~B}$ : cena.

${ }^{80} \mathrm{~B}$ : luaidid (? manuscript stained here).

${ }^{81}$ [solud céin beithi i mbethaid]; B: solud na senairecht ce no bethtai a mbethaigh

${ }^{82}$ [Connach coir ... to end]; B: Is ass[?] sin nach coir doiduine solad $h$ na senairecht do cuinnc[...?] air is e in Coimde connic na huile eter maith ${ }_{77} \mathrm{~s}$ [h] aith et cetera.
} 
(§3) 'You are welcome,' said the layman. 'You will have my goods. Give, indeed, your goodness to me, i.e. praying to God for me.'

That is done. They go, and they went around the burialplace and relics of Peter and Paul. They come back from the east.

(§4) 'Let a dwelling-place be sought, so that it may be vacated for you.'

'There is a little hermitage here. There is a wretched hermit in it.'

'Let him be told to come out of it,' said the king.

'I give thanks to God,' said the hermit: 'My earthly king ejecting me; my heavenly king coming into it. Go into it now, o clerics.'

'May it be lucky,' said the cleric.

'What is it that they are saying?' said the king.

'May it be lucky for them.'

'Out of the country with them!' said the king, 'they are heathens! Let them not even drink the water of the country.'

(§5) They go off for the course of that day until they reached a city there. The bishop, i.e. their leader, was washing his hands in the river the following day, and he saw a wooden chest [coming] towards him against the current of the river. It leaps from below so that it was in the bosom of the cleric.

(§6) 'Take this with you, o lad, to the king,' said the cleric. 'I do not know what is in it.'

It is brought to him then. He has it opened, so that he saw six bars of silver in it and a bar of red-gold among them. He had them put into a weighing scale. There was not the weight of a mite in any one of them more than another. 'Well,' he said, 'let the clerics be summoned to us.'

(§7) They arrive then.

'Well, o clerics, here is our interpretation of these seven bars thus, that is, the six bars of silver, they are the weekdays; the gold bar, that is Sunday. What I see is that no one of them is heavier than another. This is its 
explanation, indeed, as no bar of these is heavier than another of them: thus is the luck of one day over another of the week. For it is one king who has granted them, and he has not granted evil on any of them more so than another. Remain, o clerics. You are good people but, on the other hand, do not think of "luck" as long as you're alive.'

(§8) So that it is not right, indeed, to adhere to luck or augury.

\section{Commentary}

(§1) It is not entirely clear how we are to understand macclérech. I have noted above (p. 11) that Etchingham has suggested that it may mean something as broad as 'clerical adherent', but it would be more in keeping with the tone of the anecdote to see our protagonists as 'junior clerics' or perhaps even 'clerical students'. Here we might compare the evidence of the Collectio Canonum Hibernensis, which gives the age of admission to the most junior clerical grade (lector/exorcist) as twenty. In the Bretha Nemed the lowest clerical grade is usher (ostiarius), the age for which is also given as twenty. ${ }^{83}$ Thus the image is suggested of students in their late teens, or junior clerics in their early twenties: either way, the image of the modern gap-year student springs immediately to mind. The young clerics are described as being do feraib Herend, using the geographical identifier fir Érenn ('men of Ireland'). Compare below the anecdote below (p. 23), where the linguistic/ethnic identifier Goídil ('Gael') is used. ${ }^{84}$

We are told that 'wine and wheat-bread' was given to the junior clerics. There is rich wordplay here. On the one hand, there is the obvious Eucharistic imagery of the offering of bread and wine. However, the primary point must be the luxurious and high status nature of both items. As Fergus Kelly has shown in his discussion of cruithnecht ('wheat',

${ }^{83}$ Hermann Wasserschleben (ed.), Die irische Kanonensammlung (Leipzig, 1885), I.11; Liam Breatnach, 'The first third of Bretha Nemed Toísech', Ériu 40 (1989), $1-40, \S 24$.

${ }^{84} \mathrm{On}$ the expression of political and ethnic identity in the post-Viking/pre-Norman era, see Máire Herbert, 'Rí Éirenn, Rí Alban, kingship and identity in the ninth and tenth centuries', in Simon Taylor (ed.), Kings, clerics and chronicles in Scotland 500-1297: essays in honour of Marjorie Ogilvie Anderson (Dublin, 2000), 62-72. 
especially 'bread-wheat'), it was the 'most prized cereal' in early medieval Ireland. ${ }^{85}$ For example, the eighth-century law-text, Bretha Déin Chécht, which lists cereal grains in order of prestige, places bread-wheat first. 'Thus a wheatgrain is equated with the rank of superior king, bishop or chief poet, whereas at the bottom of the scale the oat-grain is equated with the commoner of bóaire rank. ${ }^{86}$ The high status of bread-wheat was connected to its rarity, resulting from the fact that the Irish climate is not conducive to its cultivation; thus, our junior clerics receiving wheat-bread from their Frankish host not only underlines the luxury of the hospitality, but also its exoticism. A similar point can be made in regards to the wine: the Irish climate is not favourable for the cultivation of grape-vines, although there may have been some small-scale and localised wine production in early medieval Ireland. ${ }^{87}$ However, the predominant source of wine in early medieval Ireland was through foreign imports, particularly from Francia. As Kelly has noted, 'Cormac's Glossary' defines an escop fina ('wine-jar') as 'a vessel for measuring wine among Gaulish and Frankish traders' (escra tomais fina la ceandaighaib Gall ${ }_{7}$ Franc) ${ }^{88}$ Kelly demonstrates further that the significance of the wine-trade is 'indicated by the prominence of Bordeaux (Latin Burdigala) - the centre of the wine-trade - in early Irish texts. The name of this town was borrowed into Irish in the form bordgal and is used in the eighth-century Félire Óengusso in the meaning "meeting-place, city" ${ }^{89}$ In offering the junior clerics both wine and wheat-bread - quite aside from the inherent and inverted Eucharistic symbolism of a layman giving bread and wine to clerics - the Frankish king is providing them with a lavish and exotic feast, which in an Irish context would be deemed fitting for persons of vastly higher rank than maccléirig ('junior clerics').

Unsurprisingly, we are told Maith doib, that is, the meal was 'good for them' (or, in a looser translation, 'they were well treated'). This is the start of a series of ironic

\footnotetext{
${ }^{85}$ Fergus Kelly, Early Irish farming (Dublin, 2000), 220.

${ }^{86}$ Ibid., 219. Kelly provides numerous other examples which show the high status of cruithnecht.

${ }^{87}$ Ibid., 262-3.

${ }^{88}$ Ibid., 319

${ }^{89}$ Ibid., 319. On the Félire, see below p. 37.
} 
usages of maith. The statement suggests both that the meal was good for them, in a nourishing and perhaps given the Eucharistic resonances - spiritual sense, and their realisation that they might be on to a good thing in Francia. This repeated and ironic use of maith continues, particularly in $\S 3$, when the Frankish king offers his 'good things' to the clerics (but, more importantly, ends up giving them his 'goodness').

(§2) The vocabulary of asceticism here is ironic, given that the junior clerics have already shown their admiration for the abundant wine and wheat-bread and now state that they want to remain in Francia because 'every produce is plentiful'. The clerics want to occupy a dísert ('hermitage') so that they can be in a state of ailithre ('pilgrimage', 'retirement from the secular world') and yet within easy reach of luxurious food and drink. This sense of irony is reinforced when a hermitage is found for them: a hermit is already occupying it, and he has to be evicted in order to make way for the Irishmen. Not only does he demonstrate self-sacrificing piety in submitting to the will of the king royal instruction reflecting, in his opinion, the will of God - but he is also described by the author as trúag ('poor', 'wretched', but also 'lean', 'emaciated'). Not only is he a true 'wretched' hermit, but the physical resonances of trúag provide a direct contrast with the gluttonous Irish clerics. Clearly the author wanted to convey a sense of scepticism about how closely the practice of exile from one's homeland was really tied to ascetic self-denial.

(§3) The Frankish host, who is later referred to as a king, is here called laech ('layman'). Since he is a pious and moral character, the reference here to him as a layman may be a pointed contrast with the immoral young clerics. He offers his 'goods' in return for their 'goodness', but they have little of the latter to offer, and the layman ends up showing them his 'goodness' as well as his 'goods'. It is possible that the fer amra, the laech and the king are not one and the same character, but if so the appearance of the king in the narrative is abrupt and unexplained (and unlike the abrupt appearance of the bishop, shows no sign of being explained through an incorporated gloss, for which see 
commentary on §5). It therefore seems to me more likely that fer amra and laech are being used to describe the king.

(§4) The junior clerics' statement, which incurs the wrath of the king, relates to solad ('luck', 'fortune', but also 'augury'). This word has strong pagan associations elsewhere in medieval Irish literature, and is particularly found in relation to druidry. Thus, for example, in the 'Voyage of Mael Duin': Luid iarom i tir Corcomruadh do fiarfaigh seoin ${ }_{7}$ solaigi do druid bai ann ('So he went into the country of Corocomroe to seek a charm and a blessing of a wizard who dwelt there'). ${ }^{90}$ The Frankish king, who appears to be a paragon of Christian virtue, takes exception to this superstitious utterance and denounces the clerics as 'heathens', banishing them from his kingdom.

(§5) The bishop appears rather suddenly the narrative, having not been mentioned before. The nature of the explanation for his presence - i. a toisechsom - might suggest that an explanatory gloss in an earlier copy has been incorporated into the body of the text. The bishop could have simply been the bishop of the cathair in which the junior clerics arrived after their exile. But he seems to be presented here as the leader of the junior clerics. It is he who finds the chest miraculously floating against the current of the river: a motif for which I have not been able to identify any parallels.

(§7) The contents of the chest are interpreted as the days of the week. Miraculously, although one of the bars is of gold, all the bars weigh the same (obviously one would expect the gold bar to be heavier), and the king interprets this as meaning that all days are created equally and therefore no one day is luckier than any other. One cannot help wondering here whether the author is making an oblique reference to the literature pertaining to Sunday observance. Numerous Irish texts outline the significance of Sunday observance and, while the author does not claim that Sunday lacks importance - Sunday is the gold bar, to the silver of the weekdays - the message of the text

${ }^{90}$ Whitley Stokes (ed. and trans.), 'The Voyage of Mael Duin', Revue Celtique 9 (1888), 447-95 at 458. Cf. also LL f. 219b, and other examples in DIL, s.v. solad. 
LAY MORALITY, CLERICAL IMMORALITY, \& PILGRIMAGE . . 21

does seem to be that one cannot only be a Christian on Sundays, and that it is one's everyday behaviour which is truly significant. ${ }^{91}$ Pious public acts, such as the junior clerics' journey to Rome, or a person's attendance at Mass, are not the key to salvation: rather, that is to be found in daily acts of Christian charity.

(§8) The purported moral of the story - that one should not adhere to 'luck' or 'augury' - seems rather false, as I have noted above, since the Irish clerics did rather well out of their heathen exclamation. Having referred only to solad earlier, the author now introduces the term sénairecht. This word appears in Recension A of Audacht Morainn, ${ }^{92}$ and also in 'Adomnán's Second Vision' where Irish Christians are excoriated for their alleged return to heathen practices such as draidecht ${ }_{7}$ génntlidecht ${ }_{7}$ sénairecht.$^{93}$ It is perhaps significant that the term is attested in texts relating to good kingship and to the immoral behaviour of supposed Christians, since these are the two central themes of Cethrur macclérech. However, we should note that, while our king is good, in the sense that he acts in accordance with Christian morality, he is at the same time successfully exploited by the junior clerics, and this idea - along with that of the dubious morality of pilgrims - is explored further in the next anecdote.

\section{EPSCOP DO GÁEDELAIB}

Epscop do Gáedelaib is preserved in two manuscripts: LL, where it follows immediately from Cethrur macclérech, and the early fifteenth-century Leabhar Breac (Dublin, Royal Irish Academy MS 23 P 16 (Cat. no. 1230), henceforth LB). The version in the Leabhar Breac is on a particularly stained folio of the manuscript, and is therefore occasionally difficult to read. Despite this, it is clear that

\footnotetext{
${ }^{91}$ On the texts which comprise the Cáin Domnaig ('Law of Sunday'), see Liam Breatnach, A companion to the Corpus iuris Hibernici (Dublin, 2005), 209-12, and references therein.

${ }^{92}$ Fergus Kelly (ed.), Audacht Morainn (Dublin, 1976), 69, §50: Abair fris, ninerbba do sénairecht, ar ni gnáth nach sénaire bed ferr ar cách.

${ }^{93}$ Whitley Stokes (ed. and trans.), 'Adomnán's Second Vision', Revue Celtique 12 (1891), 420-43 at 428, §16. For a recent study of omens and portents, and their pagan associations, in medieval Irish literature see Mark Williams, Fiery shapes: celestial portents and astrology in Ireland and Wales, 700-1700 (Oxford, 2010). Unfortunately Williams does not discuss these precise terms or examples, but he does provide a useful contextual overview.
} 
there are some significant differences between the two versions and it seems likely that LB is based on a separate exemplar from LL. It appears that the LB version has been reworked, perhaps in the Early Modern Irish period, since it contains a number of Early Modern Irish forms. For this reason, I provide both versions separately below.

The text centres on a bishop of the Gaels who has travelled to Rome on pilgrimage. He decides to continue his journey so that he might put his arms around the cross of Christ (I assume that this refers to going either to the Holy Land or to Constantinople). On the way, he meets a king, who tells him that, since God is to be found everywhere, he would be as well to stay with the king and act as his spiritual director. A church is built for him within the king's main fortress. However, we are told that the king is often away at his other fortresses, while the queen remains at home. The queen goes to the bishop frequently to make her confession, and eventually they begin an affair. The affair continues for some time in secret, but in time the king hears about it. He besieges the stone house where the queen and the cleric are in bed together. The cleric sees the value of a hasty repentance to God, but - apparently unaccustomed to more pious forms of physical exertion - he passes out while performing prostrations. Angels carry him to his own church, where a man overhears him celebrating nocturns. The king repents of his apparently false accusation of adultery and the cleric magnanimously - forgives him. The cleric bids the king farewell and carries on to the Holy Land, and the queen is paid compensation for the defamation caused by the 'false' accusation of adultery. We are told in conclusion that the spiritual direction of God is dearer than the spiritual direction of men, since God forgave the céle Dé his sins, when men did not.

\section{Language}

The linguistic evidence indicates that Epscop do Gáedelaib may be slightly (but not much) later than Cethrur macclérech. Where Cethrur macclérech preserves many Old Irish features, Epscop do Gáedelaib should perhaps be placed more firmly into the Middle Irish period: we might date it (very tentatively) to the tenth or eleventh century, though no later than that. Certainly neither of the texts discussed here displays (in the versions preserved in LL) linguistic features as late as those of some other LL texts. ${ }^{94}$ The LB

\footnotetext{
${ }^{94}$ Compare, for example, the texts discussed by Uáitéar Mac Gearailt, 'The language of some late Middle Irish texts in the Book of Leinster', Studia Hibernica 26 (1991$2), 167-216$, which are clearly later than either of our anecdotes.
} 
LAY MORALITY, CLERICAL IMMORALITY, \& PILGRIMAGE . . 23

version of Epscop do Gáedelaib does contain some very late Middle Irish or Early Modern Irish forms, but these are not found in the LL version and so can be assigned to a later reworking of the text. Early forms include the use of conid (Class $\mathrm{C}$ neut. inf. pronoun in $\S \S 1$ and 6); dia thrathaib ( $\$ 3$, but cf. dá béim in the same sentence); ríg $n$-amra $n$-and (\$2, nasalisation after accusative; see also $\$ 6$ la trócaire nDé); erumsa (\$2); and perhaps the reduplicated future Atchichera (§4: this continues to be found in Middle Irish, although the $f$-future may be the more expected form). We might also note the very interesting sentences in $\$ 3:$ I ndúnadaib ata menciu na rríg thair. Ifos immurgu bite na rígna, where the relative forms - ata and bite - would indicate an early date, and yet the use of those relative forms following adverbial phrases is indicative of Middle Irish. In the same paragraph, dúne ( $\$ 3$, with dún acting as an s-stem rather than an o-stem) may be significant, although DIL states that both forms are found in the later language. Middle Irish forms include: $c o$ tartur ( $(1$, for Old Irish tarat); dá béim (§3, but we have noted above dia thrathaib in the same line); regatsa ( $\$ 8$, for rega-sa); ro immir (§6, for Old Irish imm-rubart); ros tócbaiset (§6, for da-rócabsat); and isna cumgaib ( $\S \S 6$ and 9 , for Old Irish isnaib cumgaib). Note also ind rigan ( $\$ 3$, for Old Irish rigain), although this may simply be scribal.

Overall the language of the LL version of Epscop do Gáedelaib seems slightly, but not substantially, later than that of Cethrur macclérech. By contrast, the LB version of Epscop do Gáedelaib, has been linguistically modernised in places, and there are a number of late Middle Irish or Early Modern Irish forms. These are noted separately in the LB version (below), as they are innovations, either by the scribe of LB or his exemplar, and are not indicative of date of composition.

\section{Edition}

Here I provide the text of Epscop do Gáedelaib from LL. The text is that of the diplomatic edition, but I have expanded didiu and iтmиrgu and have added punctuation, capitalisation and paragraph divisions silently to reflect my interpretation of the text.

\section{Text}

(§1) Epscop do Gaedelaib dochoid do Róim conid ránic ${ }_{7}$ co turcaib in cloich.

'Maith dam,' or se, 'tect co tartur mo di láim im chroich Crist.' 
(§2) Teit ass iarum co rranic ríg n-amra n-and, dogníside failte fris. 'Cid no thegi a chlerig?' or in rí.

'Do chosnam ám na croche dús i tardaind mo dí láim impe.'

'Maith a chlerig,' or in rí, 'atá Dia in cach dú. Cid na hanai limsa co ndernaindse cennach frit i. tussu do guide Dé erumsa ${ }_{7}$ meisse do denam neich ortsu, corop tussu bes anmchara damsa?'

'Déntar ém,' or in clerech.

(§3) Dognither eclas dó for lár in dúne. \& cloc inna láim dá béim dia thrathaib. Ór argat ind ríg acai i tascid. Ni theiged in rí immach nach i tech co ndechsad chucaiseom ${ }_{7}$ ind rigan do thabairt choibsen dó. I ndúnadaib ata menciu na rríg thair. I fos immurgu bíte na rígna. Ba menciu dano ind rigan do thabairt a coibsen dó. Dorala tra dóib comtar oentadaig in t-epscop ${ }_{7}$ ind rigan. Bátar amlaidsin ri ré cían cen fís. Rofes immurgu iar tain, co cúala in rí.

(§4) 'Ni fír,' or seside. 'Ni chretiubsa ó duni conid n-accur féin.'

'Atchichera immurgu,' or in marntid. 'Is and foit it daimliacso, in tan nad bísiu i fus.'

'Maith,' or in rí, 'bíd forcomet forru. Tiagsa amal bid i ndúnad.'

Dognither ón. Tiagait-seom ina ndamliac. Ro boí in forcomet forru. Dothaet in rí tráth do aidchi co mbuí immon damliac cona ṡluagaib imme.

(§5) 'In fail in clerech is taig?'

'Cia so?' or in ben.

'Atá in rí sund oslaic remi.'

'Bale i rrabi costrasta bíd and co matin.'

'Ní messu caimda in chlerigsin.'

'Bid aithrech in lanamnus.'

'Cumma,' or in rí.

Saidid immon tech co matain.

(§6) 'Olc so a mmo Chomdiu,' or in clerech. 'Atusa orbam noídiu 'cot fognam cossinnocht. conid hé mo iartaige dul a drochgnimaib dochum n-ifirn. Is cobair tra,' or se, 'in díanaithirge.' 
LAY MORALITY, CLERICAL IMMORALITY, \& PILGRIMAGE . . 25

Ro immir a chorp co ndernai tri chét slechtain conid rala hi tasse. La trócaire ṅDé didiu amal doreithseom a munter isna cumgaib ros tócbaiset angil co mbaí fora dérgud inna eclais fessin. Fer didiu luid timchell conid cualai oc celebrad íarmerge ina eclais.

(§7) 'Ni hed for scél; atá in clerech oc celebrad.'

'Bid olc ar n-iartaige,' or in rí. 'Dorega tene do nim ornd.' Is amlaid dochóid in rí chucai ${ }_{7}$ cach slechtain a cind araile leis co rranic in n-eclais.

(§8) 'Gebthair,' or in clerech. 'Ni horm m’óenur ro himred athise o Diabul. Benacht latso,' or se. 'Regatsa a lleth tarmartus co rrís croich Crist.'

Celebraid don ríg, ${ }_{7}$ luid iarum co tarat a dí láim im chroich Crist, \& doratad dano a lúag don banscáil ar anad lasin ríg.

(§9) Is maith didiu doreith Dia a muintir isna cumgaib, conid andso anmcharde Dé oldás anmcharde doíne. Is suachnid ón sund ar niro logsat doí[n]e a phecda don cheliu Dé deseo $_{7}$ ro $\log$ Dia.

\section{Translation}

(§1) A bishop of the Gaels went to Rome until he reached it and he lifted the stone.

'[It would be] good for me,' he said, 'to go so that I may put my two arms around Christ's cross.'

(§2) He sets off then until he reached a wonderful king there. He makes him welcome.

'Where are you going, o cleric?' said the king.

'To seek out the cross, indeed, to see if I might put my two arms around it.'

'Well, o cleric,' said the king, 'God is in every place. Why don't you stay with me so that I might make a bargain with you, namely, you to pray to God for me and me to do something for you, so that it may be you who may be a spiritual director to me?'

'Let it be done indeed,' said the cleric.

(§3) A church is made for him in the middle of the residence and a bell in his hand to ring for his canonical hours. The 
gold and silver of the king he had for safekeeping. The king used to go neither out nor inside without going to him - and the queen also - to make confession to him. It is in encampments that the eastern kings most frequently are. It is at home, indeed, that the queens are. It was more frequently, then, that the queen gave her confession to him. It happened to them, then, that the bishop and the queen were united. They were thus for a long time without it being known. It became known, however, after a time, so that the king heard.

(§4) 'It is not true,' he said. 'I will not believe it from anyone until I might see it myself.'

'You will see it,' said the informer. 'It is there that they sleep, in your stone mansion, when you are not at home.' 'Well,' said the king, 'let there be guarding upon them. I will go as though it were into an encampment.'

That is done. They go into their stone mansion. The guarding was upon them. The king comes one time at night so that he was about the stone mansion with his troops around him.

(§5) 'Is the cleric inside?'

'Who is this?' said the wife.

'The king is here: open [up] for him.'

'The place in which he was until this time, let him be there until morning.'

'The bed of that cleric is not worse.'

'The marriage will regret it.'

'Much of a muchness,' said the king.

He besieges the house until morning. ${ }^{95}$

(§6) 'Bad is this, o my Lord,' said the cleric. 'I have been since I was a child - serving you, until tonight, so that it is my final lot to go, as a result of evil deeds, to hell. However,' he said, 'swift repentance is helpful.'

$\mathrm{He}$ exercised his body so that he made three hundred prostrations until he fainted. On account of the mercy of God, then, as he helps his community in dire straits, angels lifted him so that he was upon his bed in his own church. A man then went around, so that he heard him celebrating nocturns in his church.

${ }^{95}$ Or: 'Besiege the house until morning!' (cf. LB, below n. 139). 
(§7) 'It's not what you think; the cleric is celebrating.' 'Our final lot will be bad,' said the king. 'A fire from heaven will come upon us.'

It is thus the king went to him, with one prostration after another, until he reached the church.

(§8) 'It will be accepted,' said the cleric. 'It is not upon me alone that disgrace has been exercised by the devil. A blessing with you,' he said. 'I will go in the direction I intended, so that I may reach the cross of Christ.'

He bids farewell to the king, and he went afterwards so that he put his two arms around the cross of Christ, and her compensation payment was given moreover to the woman for remaining with the king.

(§9) It is good, then, that God helps his community in dire straits, so that the spiritual direction of God is dearer than the spiritual direction of men. This is obvious in this case, for people did not forgive the client of God for his sins, and God did forgive.

\section{Epscop do Gaedelaib from $\mathrm{LB}^{96}$}

I have expanded abbreviations, and added punctuation, paragraph divisions and capitalisation to reflect my reading of the text. I have supplied some possible readings where the manuscript is illegible, based either on comparison with LL or in some cases simply the most plausible reading given the number of illegible letters.

[p. 260a50]

A marrath fil forsin ernaigthi is ed tuicter triasin scel-sa sis. ${ }^{97}$

\footnotetext{
${ }^{96}$ Previously edited by Georges Dottin, Manuel d'irlandais moyen (2 vols, Paris, 1913), ii, 132-4. Images of the manuscript are available at www.isos.dias.ie Unfortunately, the relevant page of the manuscript is badly stained, so I have had to rely primarily on the nineteenth-century facsimile. However, it is obvious that the page was already in poor condition when Ó Longáin made his copy, since there are many illegible letter spaces even in the facsimile, and in some cases I suspect Ó Longáin's transcription may be inaccurate, since it occasionally makes no sense at all: Samuel Ferguson et al. (eds), Leabhar Breac: the Speckled Book, otherwise styled Leabhar Mór Dúna Doighre, the Great Book of Dún Doighre ... (Dublin, 1876).

${ }^{97}$ In rubricated box. 'The great bounty which is upon the praying/prayer, it is it which is understood through this story here below'.
} 
(§1) Epscop uasal do Goedelu ${ }^{98}$ do-choid do Roim con $<$..>cian di. ${ }^{99}$ 'Maith dam,' ol ${ }^{100} \mathrm{se}$, 'in sin toct ${ }^{101}$ co tucar $^{102}$ mo di laim ba ${ }^{103}$ croich Crist.'

(§2) Teit as iarum co ranic rig n-amrai. Do-gni<ther?> failti mor fris.

'Cid thusa ${ }^{104}$ a clérig,' ol in rig. ${ }^{105}$

'Do ascnam em na crochi dus in roisind ${ }^{106}$ mo di laim impe,' or in clerech. ${ }^{107}$

'Maith, a clerig,' ol in rig, 'ata Dia in cech du cid na hanaid ${ }^{108}$ ocum-sa co ndernaind cendach frit .i. tusu do guide De orum-sa ${ }_{7}$ mesi do denam do riara-su. ${ }_{7}^{109}$ corap tu bus anmchara dam ar is marb m'anmcharu isna híb laib-sea.' ${ }^{110}$

'Dentar amlaid,' ${ }^{111}$ or in clerech.

(§3) Do-gnithit ${ }^{112}$ eclais don clerech for lar in duine. ${ }^{113}$ Or indmas indti oca ica taiscid. ${ }^{114} \mathrm{Ni}$ theged lin rig/ himach na i tech cen ac<allaim in? > clerig. ${ }^{115}$ ba menic tra teged in rigan aræn frisin rig dia acallaim ${ }_{7}$ do-bered a coibsena dó. ${ }^{116} \mathrm{Hi}$ sluaigedu didiu ata menciu na rig tair is na rigna

\footnotetext{
${ }^{98}$ The accusative plural here is a late form; LL has the older dative form.

${ }^{99}$ This is incomprehensible to me and is perhaps unrecoverable.

${ }^{100}$ This is the older form. LL has or.

${ }^{101}$ Later variant of techt.

${ }^{102}$ From do-ucc, whereas LL has co tartur.

${ }^{103}$ An Early Modern Irish form.

${ }^{104}$ The manuscript is illegible here, so this may be a mistranscription by Ó Longáin, given that it does not make sense in this context.

${ }^{105}$ Frequently, rig is used rather than rí. This is an Early Modern Irish feature.

${ }^{106}$ Past subjunctive of ro-saig; cf. LL: tardaind.

${ }^{107}$ This speech marker is not in LL.

${ }^{108}$ This is either a 2 plural form, perhaps denoting a polite form of address, or simply a non-historical $d$ at the end of the word. The former is more likely since we have an unambiguous example below (n. 125).

109 'your wish/desire'.

110 'since my spiritual director died in recent days'. Not in LL.

111 'Let it be done so'.

112 The manuscript is very hard to read here, and this could be a mistranscription for do-gnither.

${ }^{113}$ A section found in LL is omitted here, namely: \& cloc inna láim dá béim dia thrathaib.

114 'And he had gold and wealth stored in it'. Cf. LL.

115 cen acallaim in clerig ('without speaking to the cleric') would fit here, and makes sense in light of the sentence which follows.

116 'It was frequently, then, that the queen used to go together with the king to speak to him, and she used to give her confessions to him'.
} 
i foistine. ${ }^{117} \mathrm{Ba}$ menic tra no athaiged in rigan d'eis in rig cusin clerech. ${ }^{118}$ Is ed tra do-rala ann cumtar oentadaig int epscop 7 in rigan. ${ }^{119}$ Do-rala didiu sin cen fhis sist fota. ${ }^{120}$ Ro-fess fa deoid. ${ }^{121}{ }_{7}$ ruc cach o 'raile co cuala in rig. ${ }^{122}$

(§4) 'Ni fír itir ${ }^{123}$ sin,' ol in rig. 'Ni chretiub-sa o dhuine conus $^{124}$ accor fen.'

'At-chithe-sa ${ }^{125} \sin$ on,' ol in mairntid. 'Is ann foídit ${ }^{126}$ hit daim liac-su cech n-aidche ${ }^{127}$ in tan nat bí-siu i fhoss. ${ }^{128}$ 'Maith,' ol in rig, 'bid forcoimet forru. 7 tiag-su amal bid i slogud.' 129

Do-gníter samlaid. Tiagat-som ina ndamliacc. Ro bui in rí i forcoimet forru. ${ }^{130}{ }_{7}$ toet $^{131}$ in ri trath don ${ }^{132}$ aidche co mbui imon dam liacc cona slogu ${ }^{133}$ immbe. ${ }^{134}$

(§5) 'In fil in clerech isin tig?' ol in rig.

'Cia so tra?' or in ben. ${ }^{135}$ 'Baile i raibe cus trat-sa bid ann co matain. ${ }^{\prime} 136$

'Ni mesu latt coemthu in clerig, ${ }^{, 137}$ ol in rig.

117 'In hostings, then, it is most frequent [that] the kings in the east [are]; and the queens at home'.

118 'It was frequently, then, that the queen used to visit the cleric, in the absence of the king'. For d'eis as 'in the absence of' or 'after the departure of', see DIL s.v. éis.

119 'It is this that happened then, that the bishop and the queen were united'.

${ }^{120}$ 'That happened then without knowledge [i.e. in secret] for a long time'.

121 'It became known finally'.

122 'So everyone brought [it] from the other [i.e. it spread from person to person] until the king heard'.

${ }^{123}$ Adverbial derivative: 'at all'.

${ }^{124}$ Middle Irish form, i.e. generalised 3rd person infixed pronoun. Cf. the older form in LL: conid.

${ }^{125}$ Another instance of use of $2 \mathrm{pl}$. form being used to address an individual (present tense being used as future).

${ }^{126}$ Early Modern Irish form. Cf. LL: foit.

127 'every night' (not in LL).

${ }^{128}$ In LB, $f h$ is commonly used to denote nasalised (not lenited) $f$. Thus we should read this as $i$ foss, cf. LL: $i$ fus. I am grateful to Liam Breatnach for this point.

${ }^{129} \mathrm{LL}$ : dúnad.

${ }^{130}$ LL: Ro boí in forcomet forru.

${ }^{131}$ The manuscript is very difficult to read here, and toet in the facsimile could be a misreading of dothaet.

${ }_{132}$ Possibly an older form than what is preserved in LL: do aidchi.

${ }^{133}$ Another instance of the use of accusative plural instead of dative plural.

${ }^{134} \mathrm{~A}$ more archaic spelling than what is preserved in LL: imme.

${ }^{135} \mathrm{LB}$ omits the sentence in LL: Atá in rí sund oslaic remi.

${ }^{136}$ It is unclear to me whether this is spoken by the queen (in reference to the king) or the king (in reference to the cleric), but I have opted for the former.

${ }^{137}$ The sense here is clearer than in LL: 'you prefer the bed of the cleric'. 
'Dia coemsaind bid aithrech.' 138

'Suidid ${ }^{139}$ imon teach co matain,' ol in ri.

(§6) 'Olc lith $^{140}$ in so a mo Choimdid,' or in clerech, 'a tosac ropsa $^{141}$ noídiu ocut fhognam cusinocht. conid he $<$ mo iar $>$ daige dul iar ${ }^{142}$ ndrochgnimaib docum n-ifirn. Is $<$ cobair tra $>$,' ol se 'in dianaithrige.'

$O$ 'trubart sin fuabraid iar sin do Dia ${ }^{143}$ co nderna .ccc. slechtan condo ${ }^{144}$ rala i taissi. La mortrocaire De no conad in felire no gabad in tan fo-fuair cobair no codlad do lige fair $^{145}$ trit ${ }_{7}$ na noim dia thocbail leo ${ }^{146}$ amal rind $<$ illegible $>$ muinnter do gres asna cumcaib a mbiit ${ }^{147}<$ ros tócbaiset?> aingil no noím chena ${ }^{148}$ in clerig ${ }^{149}$ co mbui fora dergud ina eclais fesin. ${ }^{150}$

(§7) 'Nine ${ }^{151}$ for scel fora tathi,' ar araile fer frisin rig. ${ }^{152}$ 'A Ata in clerech oc celebrad ina eclais fesin.'

'Bid olcc [260b] ar n-iartaige diar n-amarus,' ${ }^{153}$ ol in rig. 'Do-raga ${ }^{154}$ tene do nim forind ind.' ${ }^{155}$ Is amlaid immorro ${ }^{156}$

138 'If I could do anything, he would be regretful'. It could be the queen speaking here (in reference to the king), but it seems more likely to be the king (in reference to the cleric). Cf. LL: Bid aithrech in lanamnus. LB then omits the 'Cumma', or in rí.

${ }^{139}$ It is clear here that this must be a 2 pl. imperative: 'Besiege the house until the morning!'.

140 'Omen', 'luck' (not in LL).

${ }^{141}$ Cf. LL: Atusa orbam. This is either a mistranscription by Ó Longáin, or a misreading by the scribe of LB: a tosac ropsa is more likely to be atosa o ropsa. If so, the ropsa is an older form than the orbam in LL.

142 'after'; cf. LL: $a$ ('as a result of').

143 'When he said that he begins to turn after that to God'.

${ }^{144}$ LL preserves an older form: conid.

${ }^{145}$ It seems likely that at least some of this was originally an interlinear gloss. The syntax is a little muddled, but makes more sense if we regard no codlad do lige fair as a gloss which has been incorporated into the main text.

146 'Through the great mercy of God, or perhaps it was the Félire that he was reciting when he got help, or sleep lying upon him, through it and the saints lifting him up with them'.

147 'as he ... his community always out of the straitened straits in which they are.'

148 'Angels or saints besides' or could be 'angels or favoured saints'.

${ }^{149}$ Could expand as clerig or clerech.

${ }^{150}$ LB omits the sentence in LL: Fer di [diu] luid timchell conid cualai oc celebrad íarmerge ina eclais.

${ }^{151}$ Possible misreading for $N i$ hé.

152 "“The situation you're engaging with is not what you think," said a certain man.'

(Lit: It is not your tidings upon which you are).

153 'for our doubt/suspicion'.

${ }^{154}$ LL has older form: do-rega.

155 'upon us for it'

${ }^{156}$ Manuscript has autem abbreviation. 
LAY MORALITY, CLERICAL IMMORALITY, \& PILGRIMAGE . . 31 do-choid in rig for amus ${ }^{157}$ in clerig ${ }_{7}$ cech slechtain hi cind araile lais co rocht cusin eclais a mbui. ${ }^{158}$ 'Geib ar sid,' ol in rig. ${ }^{159}$

(§8) 'Gebthar,' or in clerech. 'Ni form m'oenur ro furmithea aithise o Diabul. ${ }^{160}$ Bendacht lat-su i fecht-su, ${ }^{161}$ ol se. 'Ragat-sa i lleth ro imraidius ${ }^{162}$ co rrís croich Crist.'

Celebraid iarum don rig. , luid co tarut a dí laim immon croich. ${ }^{163}$ Ocus didiu. do-ratad log ।mor/ don rigain ${ }^{164}$ ar anad icon rig.

(§9) Is maith tra soerus ${ }^{165}$ in Coimdíu a muintir asna cúimcib a mbiit. ${ }^{166}$ Conid andsu anmchardine na ndoíne. oldas anmchardine Dé. ${ }^{167}$ Is follus ${ }^{168}$ ón ar niro logsat doíne a pheccdai don cheli Dé-seo ${ }^{169}{ }_{7}$ ro dilig Dia duilech. ${ }^{170}$

Diamair isin fhelire ini $<\ldots>>171$

\section{Commentary}

(§1) The bishop is described as being do Gáedelaib ('of the Gaels'). We might compare above (p. 13) the use in Cethrur macclérech of do feraib Herend, a geographic rather than ethnic signifier. LB describes the bishop as uasal ('noble'), but this might be in imitation of the preceding narrative in LB (p. 259, b m) Scel Choirpri Chruim which begins Epscop uasal robui hi Cluain meic Nois ...

The reference to the bishop reaching Rome and lifting the stone (only LL, as LB is illegible, and then incomprehensible,

\footnotetext{
157 'towards'.

158 ' until he reached the church in which he was'.

159 “"Accept our peace," said the king'. This is not in LL, but makes more sense of what follows.

160 'It is not on me alone that revilings were put by the devil'.

161 'now'.

162 'which I had intended/contemplated'.

163 ' around the cross'.

164 'a great compensation payment to the queen'; cf. LL: 'her compensation payment ... to the woman'.

165 'that the Lord frees his ...'

166 'out of the straits in which they are'.

${ }^{167}$ Meaning of ansu is opposite in LB to what it is in LL: 'more difficult' versus 'more dear'.

168 'clear'/'obvious'

${ }^{169}$ Cf. LL: cheliu Dé deseo.

170 'God of creation did forgive'.

${ }^{171}$ In rubricated box. Illegible word could be insin, with what looks like $i$ actually
} being the downstroke of an $s$, thus reading: 'That is a mystery in the Félire'(?). 
at this point) is very perplexing. I can think of a number of possible explanations, although none of them is particularly convincing. The closest parallel I have been able to find is in the Collectanea Pseudo-Bedae, $\$ 20$ :

Quaero barbarum quem inuenire non possum. In aquilonali parte ciuitatis, ubi aqua attingit parietem, tolle saxum quadratum, ibi inuenies barbarum.

('I seek a barbarian whom I am unable to find. In the northern part of the city, where the water reaches the wall, lift up a square stone and there you will find the barbarian.') $)^{172}$

Mary Garrison has described this statement as 'puzzling' but has suggested that it might be a reference to Regensburg. She offers a number of examples of sources from the Carolingian period and later, which refer to lifting stones in Regensburg and finding barbarians under them. ${ }^{173}$ It is possible that there was a body of lore (or a proverb) related to the statement in the Collectanea which might make sense of our own bishop 'lifting the stone' in Rome, but this is by no means certain.

The DIL offers only one example of a similar phrase, but that refers very literally to someone lifting a stone (as a show of strength). ${ }^{174}$ We might think more figuratively, in terms perhaps of erecting a memorial of some kind, or making an inscription, such as the graffiti left by visitors to Rome, but I am aware of no other evidence of this sort of practice being undertaken by Irishmen in the tenth or eleventh centuries. ${ }^{175}$ There is some evidence of Irish pilgrims to Rome bringing back fragments of amphorae and similar items, perhaps as souvenirs, but this does not

\footnotetext{
${ }^{172}$ Martha Bayless and Michael Lapidge (eds and trans.), Collectanea PseudoBedae, in Scriptores Latini Hiberniae 14 (Dublin, 1998), 122-3 (\$20). I am very grateful to Dr Debby Banham for alerting me to this statement in the Collectanea.

${ }^{173}$ Note in Bayless and Lapidge (eds), Collectanea, 206-7.

${ }^{174}$ Thes. Pal. II, 344.18: ... co tuargib in cloch ... ('so that he [Lugaid] raised the stone'), from the commentary on Broccán's Hymn.

${ }^{175}$ For discussion of Anglo-Saxon evidence, see Richard Sharpe, 'King Caedwalla's Roman epitaph', in Katherine O'Brien O'Keeffe and Andy Orchard (eds), Latin learning and English lore: studies in Anglo-Saxon literature for Michael Lapidge (2 vols, Toronto, 2005), i, 171-93; Joanna Story, 'Aldhelm and Old St Peter's Rome', Anglo-Saxon England 39 (2010), 7-20.
} 
LAY MORALITY, CLERICAL IMMORALITY, \& PILGRIMAGE . . 33

seem to be what is being conveyed in the phrase co turcaib in cloich: perhaps a more plausible possibility is lifting the tombstone (of St Peter?) to collect earth from underneath it to bring home as a form of relic. One wonders also whether there may be a pun on Peter, as the 'rock' upon which the Church is built, embedded in the statement. A more negative approach might be to say that, given the garbled text in LB, the LL scribe has just tried to make sense of something illegible in his exemplar. Overall, though, I suspect that this is an allusion to a practice which would have been understood by a medieval audience.

(§2) The king states that God is everywhere equally, so the bishop is as well to stay with him as to continue on his pilgrimage. This is an important topos in western European religious thought during the Middle Ages, and for detailed discussion see below ( pp 42-6). The king suggests establishing a relationship of joint obligation, whereby he will provide the bishop with a church and royal patronage, and the bishop will act as his anmcharae ('spiritual director' or 'confessor'). This is an important term, which pertains to the relationship between clerics and laity in early medieval Ireland. For example, according to the 'Monastery of Tallaght' and the 'Teachings of Mael Ruain', ecclesiastical tenants (described as déisi, 'tenants', and aes tuaithe, 'laity') of the community at Tallaght were entitled to receive anmchairdes ('spiritual direction'), along with preaching, the Eucharist, and other aspects of pastoral care. ${ }^{176}$ The key elements of anmchairdes appear to have been the practice of confession and the administration of penance. Documents associated with the céli Dé suggest that sexual continence was also an important regulation for married laymen and women who were under 'spiritual direction' and so perhaps, on a more humorous note, we are to suppose - given what unfolds subsequently - that the queen, as the wife of this pious king seeking anmchairdes, is somewhat sexually frustrated. ${ }^{177}$

\footnotetext{
${ }^{176}$ Westley Follett, Céli Dé in Ireland: monastic writing and identity in the Early Middle Ages (Woodbridge, 2006), 177, and references cited there.

${ }^{177}$ Follett, Céli Dé, 178, 182.
} 
(§3) A church is built for the bishop in the middle of the royal fortress, and he is provided with the accoutrements necessary for observing the Divine Office. We are also told that the gold and silver of the king was given to him for safekeeping. In one sense this is a metaphor for the fact that the real wealth of the king is his honour and spiritual well-being: these are both given to the bishop 'for safekeeping', but he fails to keep them safe at all. But one wonders whether there is also a genuine practice which is being referred to here, namely the custom of offering ecclesiastical sanctuary to goods as well as to individuals. A. T. Lucas suggested that 'the custom of sanctuary in churches extends to lay property as well as to lay persons', ${ }^{178}$ and he noted annalistic evidence which seemed to support this notion, such as the entry in the Annals of Inisfallen s.a. 1180: 'the plundering of Inis Faithlinn by Mael Dúin son of Domnall Ua Donnchada, and the carrying off by him of all the worldly wealth therein, which was under the protection of its saints, clerics and consecrated churches. He collected, indeed, the gold, silver, trappings (?), mantles, and cloaks of Iarmumu, without any respect for God or man'. ${ }^{179}$

The observation that it is the custom of eastern kings to be away at their encampments (or simply 'residences') while their queens remain at home, is found elsewhere in LL: Dunad dano lasna rigu thair do grés. Oc ól immurgu, oc tomailt bite na rígna i foss. ${ }^{180}$ One wonders here whether this statement regarding the mobility of 'eastern kings' describes the iter regis characteristic of much of early medieval European kingship. ${ }^{181}$ The king would travel constantly with his retinue (which might number several hundred individuals); since early medieval kingship was largely charismatic, rather than institutional, the presence of the king was required in order to enforce his authority. The use of dúnad to describe the places where the kings reside is particularly reminiscent of Carolingian kingship:

\footnotetext{
${ }^{178}$ A.T. Lucas, 'The plundering and burning of churches in Ireland, 7th to 10th century', in Etienne Rynne (ed.), North Munster studies: essays in commemoration of Monsignor Michael Moloney (Limerick, 1967), 172-229, with the discussion of 'Sanctuary of property' at 194-208 (quotation at 194).

${ }^{179}$ Lucas, 'The plundering', 197. Cf. also AFM 949 (Lucas, 'The plundering', 199).

${ }^{180}$ Best et al. (eds), Book of Leinster, p. 1224, 1. 36320.

${ }^{181} \mathrm{John} \mathrm{W}$. Bernhardt, Itinerant kingship and royal monasteries in early medieval Germany c. 936-1075 (Cambridge, 1993), 45-70.
} 
LAY MORALITY, CLERICAL IMMORALITY, \& PILGRIMAGE ... 35

as Julia Smith has noted, many Carolingian royal residences, such as Aachen, Nijmegen, Frankfurt and Regensburg were located on Roman foundations, which were 'small semi-rural establishments or old army camps on the northern Roman periphery'. ${ }^{182}$ 'Frontier warfare' was also a characteristic of their Ottonian successors. ${ }^{183}$ Peripatetic kingship seems likewise to have been the norm in Ireland and, as is the case here, the frequent absence of the king can be used as a convenient narrative device (for example, in Tochmarc Étaíne). In this anecdote, it allows for the affair to develop between the queen and the bishop, as a result of the former's regular visits to the latter for confession. In a recent study of two anecdotes associated with the writings of the céli Dé, Westley Follett has commented perceptively on the idea that frequent confession could lead to sexual desire between the two parties concerned, and he has noted that ecclesiastical writers were well aware of the moral risks inherent in close spiritual relationships between women and their male confessors. ${ }^{184}$

(§4) The royal dwelling is described throughout as a damliac (which I have translated here as 'stone mansion'). See for example, the definition offered in O'Mulconry's Glossary and cited in DIL: daim liacc .i. tegduis cloch ('i.e. a stone dwelling/mansion'), but note also the many ecclesiastical examples given there. One significant aspect of the term is that it denotes a stone, as opposed to a timber, construction, but there are also important ecclesiastical resonances. The repeated statement that the residence was made of stone seems to suggest the exoticism of the king's court. There certainly seems to have been a perception that stone buildings - especially churches - were not native to pre-Norman Ireland, but rather were characteristic of foreign lands. We can see this, for example, in Bernard of Clairvaux's twelfth-century Life of Malachy of Armagh, in

\footnotetext{
${ }^{182}$ Julia M. H. Smith, Europe after Rome: a new cultural history, 500-1000 (Oxford, 2005), 191.

${ }^{183}$ Smith, Europe after Rome, 196-7.

${ }^{184}$ Westley Follett, 'Women, blood and soul-friendship: a contextual study of two anecdotes from the Tallaght Memoir', in Sarah Sheehan, Joanne Findon, Westley Follett (eds), Gablánach in scélaigecht: Celtic studies in honour of Ann Dooley (Dublin, 2013), 53-68.
} 
which Malachy is reported to have begun building a stone oratory at Bangor. One objector to the building project is reported as having said Scoti sumus, non Galli ('We are Irishmen, not Frenchmen'). ${ }^{185}$ However, there were mortared stone churches built in eighth and ninth century Ireland, and there was a growth in stone construction in the tenth and eleventh centuries (i.e. the time at which our anecdote was composed). ${ }^{186}$ We might also note the role of kings in commissioning most of the early stone churches. ${ }^{187}$ The ecclesiastical resonances evoked (no doubt deliberately) by the term damliac, emphasise the sacrilegious nature of the relationship between the queen and the bishop, and suggest that the royal residence (rather than the church) is the locus of sanctity in the anecdote. But I also think we are supposed to see a contrast between the exotic building methods of the 'eastern' kings and the royal residences of early medieval Ireland.

(§5) Here we get some dynamic back-and-forth dialogue between the queen and the king (or his messenger), and it is not always clear who is speaking at any given time. The LB version is somewhat clearer, since there are additional speech markers, but perhaps this reflects later intervention by a scribe trying to make sense of the dialogue, rather than the original intention of the author. My use of punctuation in the text reflects my interpretation, but other readings may be equally possible. The essential points are that the queen and cleric are accused of adultery; the queen tries to buy time for herself and the cleric by suggesting that nothing should happen until morning; and the king besieges the house overnight.

(§6) The cleric suddenly sees the value of a 'swift repentance' (dianaithirge) and begins to perform three hundred prostrations (or genuflections) 'until he fainted'. This would suggest that he was unused to performing such physical feats of piety, despite the fact that performing daily prostrations seems to have formed part of the Divine

${ }^{185}$ Bernard of Clairvaux, The life and death of Malachy the Irishman, trans. Robert T. Meyer (Kalamazoo, MI, 1978), 77, §XXVIII.61.

${ }^{186}$ Tomás Ó Carragáin, Churches in early medieval Ireland: architecture, ritual and memory (New Haven and London, 2010), 5, 7.

${ }^{187}$ Ó Carragáin, Churches in early medieval Ireland, 7. 
LAY MORALITY, CLERICAL IMMORALITY, \& PILGRIMAGE . . 37

Office for those who identified themselves as céli Dé (our cleric being identified as such at the end of the text, §8). As Westley Follett has noted, 'where in earlier centuries there was some tolerance of married clergy, céli Dé seem to have expected celibacy of all those in orders whether or not they were under monastic vows'. ${ }^{188}$ According to the 'Old Irish Penitential', the penalty for a bishop who fails to remain chaste is that he should be degraded, and do penance of either twelve years with only water to drink, or seven years on a diet of bread and water. ${ }^{189}$ For our lucky bishop, however, only a hasty attempt at prostrations was needed in order for God to intervene miraculously, save him from the king, and enable him to continue with his foreign pilgrimage.

The variants in LB are intriguing here, particularly the introduction of the Félire Óengusso as an instrument of salvation for the sinful bishop, something which ties the text ever more closely to the interests of those identified as céli Dé. ${ }^{190}$ Although the syntax is a little unclear, we are told:

La mortrocaire De no conad in felire no gabad in tan fo-fuair cobair no codlad do lige fair trit na noim dia thocbail leo ... ( $L B \S 6)$

('Through the great mercy of God, or perhaps it was the Félire that he was reciting when he got help, or sleep lying upon him, through it and the saints lifting him up with them ...')

The alternative explanations offered here suggest that the LB scribe may have incorporated an interlinear gloss into the text at this point: perhaps at some point a (humourless?) interpreter thought that reciting the Félire could explain God's decision to save the sinful bishop, and the scribe of LB thought it fitting to include this in the main text. ${ }^{191}$ This makes particular sense within the

${ }^{188}$ Follett, Céli Dé, 182

${ }^{189}$ Follett, Céli Dé, 181.

${ }^{190}$ Whitley Stokes, ed. and trans., Félire Óengusso Céli Dé: the martyrology of Oengus the Culdee (London, 1905; repr. Dublin, 1984).

${ }^{191}$ See also the conclusion of the LB version, which suggests that the purpose of Epscop do Gáedelaib was to reveal the extraordinary 'mystery' of the Félire, an interpretation which is not supported by LL. 
context of LB, which preserves numerous texts associated with the céli Dé, including a version of the Félire itself, as well as the linguistically reworked (from Old to Middle Irish) version of the so-called 'Tallaght Memoir', namely the so-called Rule of the Céli Dé. ${ }^{192}$ The associations between the Félire and the documents connected to the céli Dé, and their shared transmission in LB, have been discussed by Follett (and references there cited). The LB version of Epscop do Gáedelaib thus offers further evidence of a perceived connection, although we should note that this is within the limited context of LB itself: the Félire is not mentioned at all in LL.

(§7) The king's repentance is far more genuine than that bishop's. His public act of remorse, prostrating himself all the way to the bishop's church, is humiliating. Royal acts of public penance could be fatal to kingship, although they could also be seen as reinforcing legitimate Christian kingship. The most obvious example is the public penance of Louis the Pious, which led to his temporary deposition, although he regained his throne within six months. ${ }^{193}$ Here, as in the previous anecdote, the king shows an error of judgement. His initial reaction had been correct; it is in retracting his earlier decision that he makes his mistake.

(§8) The cleric forgives the king, but decides - rather wisely, given the circumstances - that he should leave and continue his journey to seek the cross of Christ. When he bids farewell to the king, the term used is celebraid, which is clearly intended as a pun, since earlier the cleric was heard 'celebrating' nocturns, but here it means to 'bid farewell'. The author is drawing a contrast between the bishop's precipitate escape and the 'celebrating' of the Divine Office, the latter being the activity to which our

${ }^{192}$ On the 'Tallaght Memoir' see Follett, Céli Dé, 101-14, and on the 'Rule of the Céli Dé', 114-21; Edward Gwynn (ed. and trans.), 'The rule of the Céli Dé', in The rule of Tallaght, Hermathena 44, second suppl. vol. (Dublin, 1927), 64-87.

${ }^{193}$ See Mayke de Jong, The penitential state: authority and atonement in the age of Louis the Pious, 814-80 (Cambridge, 2009); Courtney M. Booker, Past convictions: the penance of Louis the Pious and the decline of the Carolingians (Philadelphia, 2009). See also Levi Roach, 'Penitential discourse in the diplomas of King Æthelred "the Unready", Journal of Ecclesiastical History 64 (2013), 258-76. An important, wide-ranging study is Sarah Hamilton, The practice of penance, 900-1050 (Woodbridge, 2001). 
LAY MORALITY, CLERICAL IMMORALITY, \& PILGRIMAGE . . 39

protagonist should rightly devote himself, rather than gallivanting off to the Holy Land.

The bishop resumes his journey eastwards, and we are told that the queen's lóg ('worth', 'value') was paid to her 'for remaining with the king'. The legal position underlying this statement is that the queen would have been entitled to divorce her husband on account of the slander which he had committed in 'falsely' accusing her of adultery. Indeed, one of the legal heptads specifically cites 'spreading a false story' about one's wife as grounds for the wife to seek divorce. ${ }^{194}$ The humiliation of the pious king is two-fold: first, he has begged forgiveness from the bishop, and paid compensation to his wife, as a consequence of his 'false' accusation; and second, we, the audience, know that he has ultimately been deceived, and that he was correct in his original accusation. His authority has been undermined, in very different ways, in the eyes of his subjects and those of the audience. Given his thoroughly moral, pious and kingly behaviour throughout the anecdote, one wonders at the message contained within his ultimate humiliation.

This legalistic reference to the queen's compensation permits us also to consider the normative relationship between clerics and laity which, I suggest, this anecdote is seeking to subvert. Córus Bésgnai ('The Ordering of Disciplines') is one of the constituent tracts of the Senchas Már. Although it has recently been argued that the Senchas Már was composed in Armagh in the second half of the seventh century, ${ }^{195}$ the evidence of its later commentaries suggest that it continued to be read and employed throughout medieval Ireland. ${ }^{196}$ Córus Bésgnai outlines the entitlement of the laity from the Church as follows:

Dliged túaithe i n-eclais, i mbí inna coir chuindligid, cuingid arthéchtae ó eclais, i. baithes ${ }_{7}$ comnae ${ }_{7}$ immain anmae ${ }_{7}$ oifrend ó cach eclais do chách iarna creitme

\footnotetext{
${ }^{194} \mathrm{CIH}$ I, 47.23: Bean o toimsi a ceile guscel. This is not mentioned in the tract specifically devoted to marriage law: Charlene M. Eska (ed. and trans.), Cáin Lánamna: an Old Irish tract on marriage and divorce law (Leiden, 2010).

${ }^{195}$ Liam Breatnach, The Early Irish law text Senchas Már and the question of its date, E. C. Quiggin Memorial Lecture 13 (Cambridge, 2011), esp. p. 42.

${ }^{196}$ See, for example, Breatnach, A Companion, ch. 7.
} 
coir, co n-aisnéis bréithre Dé do chách inda-túaisi noda comalnathar. Cach ord íarna chiurt, co n-imochid a n-audbart, a ndechmad, a prímite a prímgeine ${ }_{7}$ a n-audacht, a n-imnae, co rabat don eclais íar n-etlae urd, co fortacht cach etail má fa-n-orr anetail nád chocra cert. ${ }^{197}$

("The entitlement of the laity in the church, when it is in proper relationship of joint obligation, is to demand prerogatives from a church, i.e. baptism, and communion, and prayers for the soul, and mass from every church to all, by virtue of the rightness of their faith, together with expounding the word of God to all who listen to it and fulfil it. Every order functioning correctly, ensuring that proper use is made of their offerings, of their tithes, of their firstfruits and of their first-borns, and their testaments, their donations, so that the church may have them by virtue of [its] state of purity, along with coming to the aid of every pure person if an impure person who intends evil assails him')

The idea that the Church will (or should) come 'to the aid of every pure person if an impure person who intends evil assails him' is essentially what is parodied in the conclusion to Epscop do Gáedelaib: God comes to the aid of the cleric simply because he is a repentant cleric (no matter that the repentance is explicitly described as 'hasty'); the king is 'impure' because he dares to accuse the cleric of sexual incontinence and besiege him, with the threat of violence, when he should - like a good Christian - have forgiven the céle Dé, as God forgives. The king had established a relationship of 'joint obligation' with the cleric, although we might observe that he got more than he bargained for in terms of ecclesiastical 'services' rendered to his wife.

(§9) The sinful bishop is described in conclusion as a céle Dé ('client of God'). Given the general attitude towards pilgrimage in texts associated with those who called themselves céli Dé, namely that it poses a threat to

\footnotetext{
${ }^{197}$ Liam Breatnach, ed. and trans., Córus Bésgnai, §38. I am grateful to Professor Breatnach for allowing me to see his working edition and translation in advance of its completion and publication.
} 
ecclesiastical discipline, and is of lesser spiritual value than obedience to one's ecclesiastical superiors, ${ }^{198}$ the description of our bishop as a céle Dé (when he is behaving more like a déorad Dé 'exile of God', who has turned to sin) is ironic. He failed spectacularly in his obligation to provide appropriate spiritual direction (anmchairdes) to the king and queen. We are told in LL that the 'spiritual direction of God is dearer than the spiritual direction of men' because men did not forgive the bishop, when God did. ${ }^{199}$ We are left thinking, however, that the spiritual direction of God might have been better for the king than the spiritual direction he received from the lustful bishop.

\section{DISCUSSION}

In her brief discussion of these anecdotes, Dagmar Schlüter placed them within the context of twelfth-century European compilations of Christian exempla. ${ }^{200}$ There are important reasons for considering their specific inclusion and juxtaposition within the Book of Leinster in such a context, of course, but their relative dates of composition demand that we also consider them in relation to the tenth and eleventh centuries, in order to understand the intentions of their authors. And, given the moral ambiguities which, I have argued, lie at the heart of these anecdotes, it is far from clear that they function as exempla in any straightforward sense. The anecdotes contain serious, moral and didactic points, but these have to be teased out, and they are open to alternative (and sometimes apparently contradictory) interpretations. The same is true of the other anecdotes which are collected along with the two we have discussed here. Close readings of these other anecdotes will undoubtedly reveal more about the purpose(s) of these texts, which seem to encompass humorous entertainment, ironic parody, moral puzzle and biting social commentary. They raise interesting questions about authorship and audience, and I hope that the present study might encourage further research into this hitherto rather neglected corpus of material. ${ }^{201}$

\footnotetext{
${ }^{198}$ For example, Follett, Céli Dé, 157, discusses Máel Rúain's disapproval of anyone who 'deserts his country' (déreich a tír).

${ }^{199}$ Taking the other meaning of ansu (i.e. in LL 'dearer' but in LB 'more difficult'), LB reverses the wording (but not the meaning) and tells us that the spiritual direction of men is more difficult than the spiritual direction of God.

${ }^{200}$ Schlüter, History or fable, 206.

${ }^{201}$ That some of these anecdotes - along with others not included in the Book of Leinster - are preserved in later medieval manuscripts, including the Leabhar Breac, Rawlinson B 512 and the Yellow Book of Lecan, is evidence of an extended interest
} 
There remains the question of the extent to which we can read these literary narratives as evidence for historical attitudes towards pilgrimage, or clerical and lay morality, in tenth- and eleventhcentury Ireland. (Or indeed, for evidence of attitudes at the time when they were copied into the extant manuscripts, although the very literal rubricated heading and ending given to Epscop do Gáedelaib in LB suggest that the scribe/author of this version might not have grasped the irony which I have argued was intended by the original author). One particularly interesting feature of the two anecdotes considered here is their use of very specific ecclesiastical terminology, drawing on the vocabulary of asceticism, of pastoral care, and of the céli Dé, something which raises questions about their authors and intended audiences. I would argue that the irreverent scepticism of their authors regarding the morality and motives of those who undertake foreign pilgrimage is important evidence of the attitude of one section of the educated ecclesiastical élite towards another. Kathleen Hughes, in her seminal study of pilgrimage in early medieval Ireland, drew attention to negative attitudes towards foreign pilgrimage which, she argued, were in part associated with the fact that (voluntary or compulsory) exile from a kingdom could be a punishment for sin and/or criminal acts. In consequence, there may have been 'irresponsible and undesirable elements among Irish exiles' ${ }^{202}$ Furthermore, the documents associated with the form of cenobitic monasticism whose adherents identified themselves as céli Dé actively privileged collective obedience over the individualism of foreign pilgrimage.$^{203}$ Medieval Irish religious literature provides us with a range of voices expressing doubt about the spiritual value of pilgrimage, such as the anonymous Old Irish quatrain Teicht do Róim, and Máel Ísu Úa Brolcháin's late-eleventh-century A Choimdiu, nom-choimét, which asks God to guard against 'profitless errands' which might cause him to leave the island of Ireland. ${ }^{204}$

The manuscript context of Teicht do Róim suggests that it was a product of the so-called 'Carolingian Renaissance'. ${ }^{205}$ Giles

in such narratives. As such, their form and function deserve further consideration.

${ }^{202}$ Kathleen Hughes, 'The changing theory and practice of Irish pilgrimage', Journal of Ecclesiastical History 11 (1960), 143-51, at 145-6. For a detailed study of the Irish legal and social context of exile in the pre-Viking era see Thomas CharlesEdwards, 'The social background to Irish Peregrinatio', Celtica 11 (1976), 43-59.

${ }^{203}$ Follett, Céli Dé, 157.

${ }^{204}$ Gerard Murphy (ed.), Early Irish lyrics: eighth to twelfth century (Oxford, 1956; repr. Dublin, 1998), no. 24 at $\$ 9$. See also the comments of Máire Herbert, 'Becoming an exile: Colum Cille in Middle-Irish poetry', in J.F. Nagy and L.E. Jones (eds), Heroic poets and poetic heroes in Celtic tradition: a festschrift for Patrick K. Ford (Dublin, 2005), 131-40 at 135.

${ }^{205}$ James Carney, 'Sedulius Scottus', in Robert McNally SJ (ed.), Old Ireland 
Constable, in a masterful study of opposition to pilgrimage in the Middle Ages, noted that the late antique Christian idea that 'what deserves praise is not to have been to Jerusalem but to have lived well among the people of Jerusalem' was rearticulated in the Carolingian era in relation to Rome. ${ }^{206}$ Prominent figures in Carolingian intellectual life voiced their concern about the value of clerical and monastic pilgrimage to Rome and its potential risk to ecclesiastical discipline. Theodulf of Orléans wrote:

Quod Deus non loco quaerendus sit, sed pietate colendus. Non tantum isse iuvat Romam, bene vivere quantum, Vel Romae, vel ubi vita agitur hominis.

Non via, credo, pedum, sed morum ducit ad astra ... ${ }^{207}$

('That God should not be sought in a place but cherished in devotion.

It does not help so much to have gone to Rome as to live well,

Whether a man's life is lived at Rome or anywhere else. It is not the road your feet take, I think, but the road of your conduct that leads to the stars ...')

Such views can also be seen in contemporary conciliar legislation and letters. For example, the council of Chalon in 813 warned against 'injudicious pilgrimages to Rome', ${ }^{208}$ and railed against clerics who thought that they could 'live negligently', purge their sins through pilgrimage alone, and then 'be able to perform their clerical function': actions which seem particularly evocative of our bishop in Epscop do Gáedelaib. ${ }^{209}$ Another voice came from Claudius of Turin, who wrote:

(Dublin, 1965), 228-50; Proinsias Mac Cana, 'Teicht do Róim', in M. Ó Briain and P. Ó Héalai (eds), Téada dúchais: aistí in ómós don Ollamh Breandán Ó Madagáin (Indreabhán, 2002), 73-89.

${ }^{206}$ Jerome to Paulinus of Nola. See also Augustine, Contra Fausem: 'God is in all places and ... is not contained or enclosed in any one place'. These examples are discussed in Giles Constable, 'Opposition to pilgrimage in the Middle Ages', in Stephan Kuttner et al. (eds), Mélanges G. Fransen, Studia Gratiana 19 (1976), 126-46. I am grateful to Professor Janet Nelson for bringing this important article to my attention.

${ }^{207}$ Theodulf of Orléan, Carmina minora 67, ed. Ernst Dümmler, Poetae Latini aevi Carolini 1, MGH, Antiquitates 1 (Berlin, 1881), 557. See Constable, 'Opposition', 128-30, and Janet L. Nelson, 'Opposition to pilgrimage in the reign of Charlemagne?', in a forthcoming Festschrift. I am grateful to Professor Nelson for allowing me to see her essay in advance of its publication.

${ }^{208}$ Constable, 'Opposition', 128.

${ }^{209}$ Nelson, 'Opposition to pilgrimage?': Sunt presbyteri et diacones et caeteri in clero constituti, qui neglegenter viventes in eo purgari se a peccatis putant et 
If you say I forbid men to go to Rome for the sake of penance, you lie. I neither approve nor disapprove that journey, since I know that it does not injure, it does not benefit, nor profit, nor harm anyone. If you believe that to go to Rome is [the same as] to do penance, I ask you ... why you have restrained so many souls in your monastery ... and have not sent [them] to Rome. ${ }^{210}$

As Janet Nelson notes, this is not opposition to pilgrimage per $s e$, but rather a concern that monastic and clerical pilgrimage might lead to a lack of ecclesiastical discipline and abandonment of one's original ecclesiastical community. The worry - expressed repeatedly by ecclesiastical writers across western Europe in the Middle Ages was that foreign pilgrimage was simply an extended holiday, which carried with it numerous opportunities for vice and immorality. This is reflected, not only in Cethrur macclérech and Epscop do Gáedelaib, but in a wide variety of other Irish texts. The result is a fundamental ambiguity about whether pilgrimage possessed inherent spiritual value.

In an episode in the (probably twelfth-century) Latin Life of Berach, previously discussed by Julia Smith, an unnamed monk is reported as having vowed to travel on pilgrimage to Rome, but was refused permission to do so by his abbot. The monk and abbot prayed together for three days and nights. The monk fell asleep and, when he awoke, he reported the following vision:

'Uidi ... me iter peregrinacionis arripuisse, in qua iuuenis quidam ualde decorus se mihi in itinere sociauit; et, marinis fluctibus transactis, recta uia eodem comite me ducente Romam perueni, et per ordinem peregrinacionem, quam uoui, cum predicto iuuene ad nutum uoluntatis mee peregi. Idem quoque iuuenis me per eandem uiam usque huc perduxit; qui cum magna hilaritate a me recedens, dixit se angelum Dei fuisse; et insuper asseruit, quod peregrinacionem quam ego voui, complete peregi'.

('I saw ... myself undertaking the pilgrim's journey, on which a very beautiful young man accompanied me. Having crossed the ocean, I reached Rome, with the same

ministerio suo fungi debere, si praefata loca attingant (i.e. Rome, Tours, 'and other places').

${ }^{210}$ Cited and discussed in Nelson, 'Opposition to pilgrimage?'. 
LAY MORALITY, CLERICAL IMMORALITY, \& PILGRIMAGE . . 45

companion leading me along the right way. With the young man, I completed in due order the pilgrimage that I had vowed to undertake, in accordance with my intention. The same young man led me back here by the same road. Departing from me with great cheerfulness, he declared that he was the angel of God and he also stated that I had completely fulfilled the pilgrimage that I had vowed to undertake.' $)^{211}$

Smith discussed this episode perceptively in relation to the spiritual and symbolic power of Rome in the early Middle Ages, but in relation to the present discussion it is notable that the monk in question was denied permission by his superior to go on pilgrimage at all. And we might also note that he was as able to encounter an angel of God within the confines of his cell in Termonbarry, Co. Roscommon, as he would have been in Rome. 'God is everywhere equally', as our eastern king stated in Epscop do Gáedelaib. As the name Róim ('Rome') gradually became a common noun, first meaning 'ecclesiastical settlement where a saint is buried', and later simply 'cemetery', all Irish Christians could be laid to rest in Rome, figuratively speaking, so that there was no inherent need to go physically to that city.

And yet clerics - and, from the eleventh century at the latest, lay people - continued, throughout the early Middle Ages, to embark on pilgrimages to Rome and other holy sites. Indeed, from the twelfth century we witness the practice of pilgrims bringing back soil from Rome to sprinkle on Irish cemeteries: unifying the physical and the figurative Rome. ${ }^{212}$ In 1076, Muredach mac Robartaig founded the priory of Weih Sankt Peter in Regensburg, apparently after stopping in that city on his way to Rome. ${ }^{213}$ This was followed in 1090 by the foundation in the same city of Sankt Jakob, which would be become the mother house of the great Irish network of Benedictine houses known as the Schottenklöster. However, once the original community had been founded in Regensburg, we might suppose that the Irish personnel of the Schottenklöster would have been deliberately and directly recruited, rather than picking up stray pilgrims on their way

${ }^{211}$ Charles Plummer (ed.), Vita sanctorum Hiberniae (2 vols, Oxford, 1910), i, 85-6 (§25); Smith (trans.), Europe after Rome, 285. See also the Irish Life: Charles Plummer, ed. and trans., Bethada Náem nÉrenn. Lives of the Irish saints (2 vols, Oxford, 1922), i, 42 (\$87).

${ }^{212}$ Diarmuid Ó Laoghaire, 'Old Ireland and her spirituality', in McNally (ed.), Old Ireland, 29-59 at 53.

${ }^{213}$ Pádraig A. Breatnach, 'The origins of the Irish monastic tradition at Ratisbon (Regensburg)', Celtica 13 (1980), 58-77 at 67. 
to or from Rome. In this regard, it is important that the practice of exile from one's own kingdom for the sake of God, a life lived within an ecclesiastical community in a land other than one's own, should be distinguished from the practice of pilgrimage. Similarly, pilgrimage by monks and clerics needs to be separated from lay pilgrimage, which seems generally to have been a less contentious issue for ecclesiastical commentators. The death, recorded in the Annals of Inisfallen s.a. 1095 for Eogan cend manach na Gaedil $i$ Roim ('Eógan, head of the monks of the Gaels in Rome'), which is suggestive of a schola Scottorum to parallel the schola Anglorum, is perhaps our strongest evidence of Irish ecclesiastical presence in Rome in this period, but there is more work to be done in this regard and it lies outside the scope of the present study.

Thomas Charles-Edwards began his classic study of 'The Social Background to Irish peregrinatio' with the following statement:

The Irish peregrini of the early Middle Ages have mainly been studied for their impact upon Anglo-Saxon England and Frankish Gaul. My primary purpose is not to discuss the relationship between Irish peregrini and the societies to which they came in their exile, but rather the relationship between the peregrini and their society of origin, early Christian Ireland. ${ }^{214}$

It remains the case, nearly forty years after Charles-Edwards wrote these words, that the Irish peregrini continue to be studied in relation to the societies to which they went, rather than those from which they came. Indeed, insofar as the ecclesiastical culture of early medieval Ireland receives attention in general accounts of western European Christianity, it is usually on account of the reputation of men who left Ireland - as pilgrims, missionaries, or scholars - and made their careers elsewhere: Columbanus, Columba, Eriugena, Sedulius Scottus, Marianus Scottus, and many others. The anecdotes discussed here shed little light on the practices of pilgrimage and exile in early medieval Ireland, and they offer little concrete evidence for Irish contact with Rome in the tenth and eleventh centuries: however, the value of these texts is that they offer important evidence of the sceptical, and sometimes scathing, attitudes of those who chose to remain at home. Their voices are consonant with those which we encounter elsewhere in medieval Europe, expressing fundamental concerns about the threat which pilgrimage posed to ecclesiastical

${ }^{214}$ Charles-Edwards, 'The social background', 43. 
discipline and obedience. Perhaps by locating these episodes on the Continent, the authors also had the liberty to comment sharply on issues of lay morality and clerical immorality whose focus lay closer to home. ${ }^{215}$ There is certainly much to explore in future regarding the role of the kings in these texts, and whether they are being praised for their piety, mocked for their naivety, or both.

Early medieval history records many men who went to Rome, but Alcuin stands out as one particularly prominent individual who, while travelling to Rome to collect the pallium for Eanbald, archbishop of York, from Pope Hadrian, was encouraged to remain on the Continent by a Frankish king with a 'rather peripatetic court'. ${ }^{216}$ Alcuin met with Charlemagne at Parma in 781 and soon afterwards abandoned York for the intellectual delights of Francia. But Alcuin's presence was not universally welcomed, and he was satirised in a poem by his rival Theodolf of Orléans, in verse which suggests that there were other pleasures on offer at the court:

Et pater Albinus sedeat pia verba daturus, Sumpturusque cibos ore manuque libens.

Aut si, Bacche, tui aut Cerealis pocla liquoris

Porgere praecipiat, fors et utrumque volet,

Quo melius doceat, melius sua fistula cantet,

$\mathrm{Si}$ doctrinalis pectoris antra riget.

Este procul pultes, et lactis massa coacti, Sed pigmentati sis prope mensa cibi.

(And let father Albinus [Alcuin] sit, about to sound forth pious words, freely about to take food in hand and mouth. Either, Bacchus, he is to demand fetched beakers of yours or hoppy liquid [beer], or perhaps he wants both, the better to teach, the better tune to lend his pipe, if he moistens the caverns of his learned heart. Begone, porridge and lumps

\footnotetext{
${ }^{215}$ This would certainly seem to be the case, given the proximity of these two anecdotes to others in the Book of Leinster featuring fictitious kings of 'the Greeks', which also offer rather biting commentaries on kingship. Cf. the comments of Erich Poppe and Dagmar Schlüter which suggest that the ecclesiastical anecdotes discussed here 'interrupt' the series of royal exempla. The anecdotes are thematically far more closely linked than Poppe and Schlüter allow: 'Greece, Ireland, Ulster and Troy: of hybrid origins and heroes', in Wendy Marie Hoofnagle and Wolfram R. Keller (eds), Other nations: the hybridization of medieval insular mythology and identity (Heidelberg, 2011), 127-43 at 132, a reference I owe to Dr Máire Ní Mhaonaigh.

${ }_{216}$ Andy Orchard, 'Wish you were here: Alcuin's courtly poetry and the boys back home', in Sarah Rees Jones, Richard Marks and A.J. Minnis (eds), Courts and regions in medieval Europe (Woodbridge, 2000), 21-43 at 22. I am grateful to Dr Jonathan Grove for drawing this article to my attention.
} 
of coagulated milk, but approach, table of spiced food! $)^{217}$

Just as some medieval writers did not welcome the intellectual competition caused by the arrival of immigrant scholars, so the countrymen of those exiles - the 'boys back home', to borrow the title of Orchard's study - could express irreverent scepticism about the motives of those who went abroad apparently in search of spiritual fulfilment. The authors of Cethrur macclérech and Epscop do Gáedelaib suggest that the journeys of such clerics might have been more to do with women and wine than pilgrimage and piety. Guy Halsall has observed that many 'previous researchers have either not noticed that a work was intended to be funny, or have rejected interpretations of late antique or early medieval works which see them as anything other than entirely earnest' ${ }^{218}$ I would argue that the texts discussed here provide examples of precisely this phenomenon, but, as with many other medieval texts, the humour is a vehicle through which serious messages are conveyed. Many a true word is spoken in jest, as I hope this study of Cethrur macclérech and Epscop do Gáedelaib has demonstrated.

\footnotetext{
${ }^{217}$ Cited in Orchard, 'Wish you were here', 36, with discussion of the passage on pp 36-7. On Theodulf of Orléans, see also above p. 43. One is struck by the thematic parallels with the poems of Sedulius Scottus and the epigram ascribed to Eriugena which further suggest that advancing one's career at the Frankish court came with many alcoholic rewards.

${ }^{218}$ Guy Halsall, 'Introduction: "Don't worry, I've got the key", in idem (ed.) Humour, history and politics in late antiquity and the early Middle Ages (Cambridge, 2002), 1-21 at 1, but see also pp 12-13 for discussion of the serious moral and political messages underlying much medieval humour. Scholars of medieval Irish literature have generally been more willing to see humour in saga literature than in overtly religious literature (see Joan N. Radner, 'Interpreting irony in medieval Celtic narrative: the case of Culhwch ac Olwen', Cambridge Medieval Celtic Studies (Winter, 1988), 42-59), but the existence of Aislinge Meic Con Glinne proves that at least some medieval Irish ecclesiastical writers were not averse to poking fun at their colleagues (and perhaps even themselves).
} 